\title{
Climate change and the conservation of marmots
}

\author{
Kenneth B. Armitage \\ Ecology and Evolutionary Biology, The University of Kansas, Lawrence, USA; marmots@ku.edu
}

Received 8 March 2013; revised 10 April 2013; accepted 24 April 2013

Copyright (c) 2013 Kenneth B. Armitage. This is an open access article distributed under the Creative Commons Attribution License, which permits unrestricted use, distribution, and reproduction in any medium, provided the original work is properly cited.

\section{ABSTRACT}

Conservation of marmots, large ground-dwelling squirrels restricted to the northern hemisphere, was impacted by direct human activity through hunting or modifying ecosystem dynamics. Regulating human activities reduced the threat of extinction. Climate change, an indirect human impact, threatens marmot survival through global warming and extreme weather events. Most marmot species occupy a harsh environment characterized by a short growing season and a long, cold season without food. Marmots cope with seasonality by hibernating. Their large size increases the efficiency of fat accumulation and its use as the sole energy source during hibernation. Marmot physiology is highly adapted to coping with low environmental temperatures; they are stressed by high heat loads. Global warming since the last ice age reduced the geographic distribution of some of the 15 species of marmots. Recent warming resulted in a movement upslope of their lower elevation boundary. This process likely will continue because warming is associated with drier unpalatable vegetation. Drought reduces reproduction and increases mortality; thus decreased summer rainfall in the montane environments where marmots live may cause local extinction. Snow cover, a major environmental factor, is essential to insulate hibernation burrows from low, stressful temperatures. However, prolonged vernal snow cover reduces reproduction and increases mortality. Montane areas currently lacking marmot populations because vernal snow cover persists beyond the time that marmots must begin foraging may become colonized if warming causes earlier snow melt. This benefit will be short-lived because decreased precipitation likely will result in unpalatable vegetation. Although some marmot populations are physiologically adapted to a warmer climate, global warming will increase too rapidly for any significant evolutionary response to dryness. The species that live in high, alpine meadows where tree and shrub invasions occur are most threatened with extinction. Captive breeding can preserve marmot species in the shortrun, but is impractical over the long-term. Widespread species are unlikely to be endangered in the foreseeable future, but local, low elevation populations will be lost.

Keywords: Climate Change; Global Warming; Marmot; Snowmelt; Hibernation; Temperature

\section{INTRODUCTION}

The currently recognized 15 species of marmots (Table 1) are restricted to the northern hemisphere [1]. The habitats occupied by marmots range from small, widely scattered alpine meadows to the wide-spread steppe environment. All species except $M$. bobak and M. monax are mountain dwellers [2]. Although habitat characteristics vary, they share the following major attributes: 1) meadow or grassland for foraging; 2) eastern to southern exposure where snow melts earlier than on northern or western exposures; 3 ) a moderate to steep slope that provides good drainage; 4) a solid structure that supports a burrowing habit and often associated with rocks or talus; and 5) typically at high elevations, above or near timberlines or if lower, in forest openings that may be of anthropogenic origin [2].

This review will be in four parts. First, I will describe the history and current situation of the species of marmots on the IUCN Red List of Threatened Species. Second, the harsh environment in which marmots live and the importance of snow cover will be discussed to establish the foundation for evaluating the potential effects of climate change on marmot biology. Third, known responses to global warming, including those following the last glacial maximum, will be described. Fourth, future possible responses to global warming will be described and will include both potential beneficial and harmful effects. 


\section{CURRENT CONSERVATION RESPONSES OF THREATENED SPECIES}

Three species currently are considered under threat of extinction (Table 1). The reasons for the listing differ for each species; human impacts are critical for all three.

The Vancouver Island marmot story illustrates how human activity at one ecosystem level can have unintended consequences on the ecosystem processes and drive a highly endangered species nearly to extinction. This species occupies sub-alpine forb-grass meadows on steep slopes where snow cover and avalanches inhibit tree growth [3]. Estimates of population numbers indicate that only 50 to 100 individuals existed in the late 1970's [3]. Beginning in 1981, the marmots colonized new habitats produced by clear-cut logging [4]. The population increased to more than 200 individuals, then declined to about 100 individuals by 1995 [5]. The clear-cuts regenerated; marmots went extinct in those habitats and continued to decline in the natural habitats to about 30 individuals in 2003 [6].

The decline apparently was driven by wolf (Canis lupus) and cougar (Puma concolor) predation [7]. Predator

Table 1. The currently recognized 15 species of marmots (Marmota). The status of those species under threat of extinction as listed in the IUCN Red List of Threatened Species, version 3.1, is indicated except for those species of least concern. Species that typically skip one or more years between successive reproductions are marked with an asterisk ${ }^{*}$.

\begin{tabular}{|c|c|c|}
\hline Scientific name & Common name & IUCN listing \\
\hline \multicolumn{3}{|l|}{ Eurasia } \\
\hline M. marmota ${ }^{*}$ & Alpine & \\
\hline M. caudata ${ }^{*}$ & Red or long-tailed & \\
\hline M. menzbieri ${ }^{*}$ & Menzbier's & Vulnerable \\
\hline M. camtschatica ${ }^{*}$ & Black-capped & \\
\hline M. himalayana & Himalayan & \\
\hline M. sibirica ${ }^{*}$ & Siberian or tarbagan & Endangered \\
\hline M. bobak ${ }^{*}$ & Steppe & \\
\hline M. baibacina ${ }^{*}$ & Gray & \\
\hline M. kastschenkoi & Forest-steppe & \\
\hline \multicolumn{3}{|l|}{ North America } \\
\hline M. broweri & Arctic or Alaskan & \\
\hline M. monax & Woodchuck & \\
\hline M. flaviventris & Yellow-bellied & \\
\hline M. caligata ${ }^{*}$ & Hoary & \\
\hline M. olympus ${ }^{*}$ & Olympic & \\
\hline M. vancouverensis ${ }^{*}$ & Vancouver Island & Critically endangered \\
\hline
\end{tabular}

populations apparently increased because deer (Odocoileus hemionus) abundance increased when additional food became available in the clear-cuts. Deer numbers subsequently declined and it is likely that wolves and cougars directed more efforts toward marmots [7]. A rigorous captive breeding and reintroduction program was established in 2003; marmot numbers increased to 300 400 by 2011 [6].

Local human populations have long utilized the endangered M. sibirica for food. However, early in the 20th century a market for skins developed in Europe and an estimated 115 million skins were prepared between 1906 and 1994 [8]. Skin production underwent a slow decline until new markets developed, particularly in China. The high price of a pelt (as much as \$7.64) increased the number of hunters and hunting pressure [9]. Hunting occurred during the reproductive season, which reduced recruitment. In 2005, hunting was banned throughout the country. The ban is ignored in some areas, but the population appears to have stabilized in other areas. The survival of the species seems assured because it thrives in areas where hunting is banned or does not occur for religious reason [9]. Over the long term, regulation of hunting must consider the use of marmots by local populations for food, fur, and medicinal products. Recent studies of the effect on extinction probabilities for the alpine marmot for three harvesting systems (constant-effort, constant-yield, and threshold) indicated that threshold harvesting in which exploitation occurs only in those years in which a population exceeds a given threshold and individuals are removed until the population reaches its threshold provided the highest mean yields in relation to extinction risk [10]. Thus, if the social and population biology of a species are used as the basis for regulating exploitation, sustained yields and a sustained population are possible.

Numbers of the vulnerable Menzbier's marmot have decreased because of past hunting, poisoning campaigns for pest surveys, overgrazing, and habitat destruction. Hence the populations have become more fragmented and breeding has decreased [11]. Restriction of hunting is necessary to reduce the extinction probability of this species.

These three species came under the threat of extinction by direct impacts on marmots or their environments by human activities. These and other species in local populations of some wide-ranging species are threatened indirectly by anthropogenic climate change. Climate change is predicted to affect marmots by increasing the temperature of their environments and by producing more extreme weather events [12]. The likely significance of warming and extreme weather events can be understood by examining the nature of the harsh environment where marmots live. 


\section{THE HARSH ENVIRONMENT}

The ground-dwelling squirrels (spermophiles, prairie dogs, marmots) evolved and radiated in North America in the Miocene and Pliocene and spread into Eurasia in the late Pliocene or early Pleistocene. All extant species evolved in the Pleistocene [13]. Early marmots probably inhabited cool and moist environments in western North America and were associated with the periglacial landscape in Eurasia [14]. The environment was characterized by cold winters and short, warm summers. During winter their herbaceous diet was unavailable; marmots are too small to accumulate sufficient fat and insulation to remain active and survive a long season of food deprivation. The alternative for marmots is to hibernate, which is facilitated by large body size. Body mass of all marmot species cycles annually and in adults varies from 3.4 to $6.4 \mathrm{~kg}$ at peak mass and from 2.1 to $3.9 \mathrm{~kg}$ at minimal mass [15]. Large body size increases energetic efficiency; fat accumulation scales directly with body mass whereas its use at colder temperatures during hibernation scales to mass $1 / 2$ [14]. However, large body size increases vulnerability to heat stress.

Marmots hibernate at low environmental temperature; typically $<10^{\circ} \mathrm{C}$ and may be $<0^{\circ} \mathrm{C}$ for some species. As a consequence, marmot physiology is highly adapted to coping with low temperature and activity is highly restricted by high temperature and solar radiation during the summer active season [14]. Water is unavailable during hibernation; marmots at that time rely on metabolic water and low conductance, which conserves water [16]. During the active season marmots obtain water from their food plants; thus drought seriously affects marmot growth and survival [17].

Hibernation may be a life-history trait that buffers marmots against climate change by allowing them to escape changes in climate and effectively expand their ecological niches [18]. Hibernation is a component of sleepor-hide behavior (SLOH), which includes the use of burrows and hibernation to avoid unfavorable conditions. An examination of 4536 mammal species for SLOH behavior found that SLOH mammals are underrepresented in the IUCN Red List Categories. These mammal species function at lower metabolism or are buffered from the changing physical environment. When IUCN contrasts were regressed on contrasts of SLOH behavior, bodymass, diet, and geographic range, all four contributed to lower extinction risk, but only SLOH behavior and geographic range were statistically significant [18]. However, this analysis does not consider the possible threat of warming during the active season of hibernators. This potential effect of climate change is of critical importance because, as described above, marmots are highly adapted to cool environments and avoid heat, impart by reducing above-ground activity when thermal stress is greatest [19-21]. The physiological response to heat stress may vary with the environmental conditions encountered by local populations. Yellow-bellied marmots from a semiarid environment are smaller, have a lower metabolic rate at higher environmental temperatures (but higher at lower temperatures), can mobilize evaporative heat loss at higher temperatures, form a more concentrated urine, and require only about half as much water per day as the larger montane marmots [16]. These differences apparently are genetic, which indicates that, given sufficient time, marmots can adapt to some degree to a warming environment. However, this ability is limited, no marmot species-population has evolved to live in a persistent warm, dry environment. Those populations that currently exist in a semi-arid environment do so where plants of high water-content, such as in irrigated meadows or lawns, occur. I conclude that if global warming produces a drier vegetation in marmot habitats, marmots will be unable to persist.

The harsh environment is primarily a consequence of snow cover or cold, stormy weather in the spring when hibernation terminates and reproduction is initiated. Because marmots have a short active, growing season, they initiate reproduction as early as possible so that reproductive females and young have sufficient time to gain mass for the next hibernation. Because of this emergence pattern, the woodchuck, alpine, and long-tailed marmots typically lose mass for several weeks after emergence [14]. When vernal conditions are unfavorable, embryos are absorbed by long-tailed and gray marmots, and probably by other species [15]. Because reproductive females accumulate much less fat than barren females, reproduction often is not possible in successive years and at least 10 marmot species skip one or more years between successive reproductions (Table 1). Some species adjust to the short growing season by initiating reproduction in their burrows before emergence [15].

Prolonged snow cover especially impacts marmot distribution, survival, and reproduction. Distribution of the tarbagan is limited by snow cover that persists beyond the time of the onset of marmot activity in the spring [22] and vast spaces are unoccupied by the long-tailed marmot because of prolonged snow cover [23]. In the Upper East River Valley, Colorado, USA, yellow-bellied marmots at elevations of 2930 to $3050 \mathrm{~m}$, where snow melt occurs later, have smaller litter sizes and a smaller proportion of females weaning litters than populations living at the elevations of 2711 to $2880 \mathrm{~m}$ [24]. When prolonged snow cover persisted in the spring of 1995, reproduction and survival decreased, several sites went extinct, and recovery of populations to typical levels was slow [25]. Females in a yellow-bellied marmot population at $3400 \mathrm{~m}$ where snowmelt occurs later in the year failed to wean litters in successive years [26] and in a 
year of unusually prolonged snow cover, no young emerged and none of the young of the previous year survived [27].

Delayed snowmelt in the spring reduced reproduction in the black-capped marmot [28] and increased mortality of young and yearling alpine marmots [29]. The importance of vernal snow cover is well illustrated by its effects on Olympic marmots. In the late 1960's, prolonged snow cover was associated with higher winter mortality of young and delayed dispersal by two-year-olds. No female weaned litters in successive years [30]. When the snowpack was greatly reduced in 2004 and 2005, half of the females bred in successive years. By contrast, in the high snow year of 2003, no female weaned a successive litter [31]. Similarly, late snowmelt reduced the weaning rate of hoary marmots [32].

Although prolonged snow cover in the spring is detrimental to marmot survival and reproduction, adequate snow cover during hibernation is critical. Sparse winter snow cover increases winter mortality of Olympic marmots [30] and decreases the probability of survival in alpine marmots [33]. Thus, marmots face a trade-off; they need heavy snow for winter, but survive and reproduce better if that heavy snow does not persist in the spring.

\section{RESPONSES TO GLOBAL WARMING}

Marmot distribution markedly contracted with warming and advance of the forests since the last glaciation. Marmot remains were found in Mexico; the closest modern marmot is $M$. flaviventris of northern New Mexico [34]. M. flaviventris retreated from low elevation southwesterly sites in California [35] and in central Colorado replaced $M$. monax, which moved to the eastern United States [14]. Similarly, marmots retreated from central Europe, $M$. marmota became restricted to the higher Alps Mountains and $M$. bobak became extinct in the middle Rhine region as reforestation occurred north of the Alps [36]. This shift in marmot distribution during global warming in Europe was associated with a shift toward smaller body size [14].

Global warming has both direct and indirect effects. Direct effects are those that impact a species directly. Emergence from hibernation by yellow-bellied marmots in Colorado were 23 days earlier in 1999 than in 1976, emergence time apparently is cued by the mean minimum temperature in April which increased over the same time period [37].

Marmots do not evolve randomly with respect to climate [38]; marmots apparently tend to occupy their climate space and shift geographic distribution as climate shifts. Ecological niche modeling (ENM) uses environmental data from a species distribution to build models to predict past, present, and future distributional patterns.
Two critical assumptions underlie ENM: 1) distribution of a species is determined mainly by climate; and 2) a species conserves its niche through time and space [39]. The shift in geographical range by yellow-bellied marmots and woodchucks described above are consistent with both assumptions. ENM was used to model the availability of suitable habitat for montane marmots in the Great Basin, North America in the present and during the Last Glacial Maximum. For the yellow-bellied marmot, the average LGM elevation was $1717 \mathrm{~m}$; the average present elevation is $1868 \mathrm{~m}$. Thus climate change resulted in an upward shift of $151 \mathrm{~m}$ in the lower elevation [39]. Similarly warming caused a rise in the lower border of snow cover for $M$. menzbieri in Uzbekistan which resulted in about $60 \%$ of its former habitat becoming drier. The population decreased because its foraging vegetation deteriorated [40]. Some Menzbier's marmots congregated near sparse springs where forage is available only to be extensively killed by herdsmen. For both of these species, climate change had an indirect effect by reducing available habitat.

A major way in which habitat loss is occurring is through the invasion of woody plants into existing habitat. The habitat of $M$. broweri is shrinking because of the abundance and upslope migration of trees and shrubs. Because this species occupies the highest elevations in the northernmost mountains in North America, there is no place to which populations can disperse; thus they face ultimate extinction [41]. Currently tree cover is increasing in alpine meadows utilized by Olympic marmots [42].

Climate change also acts indirectly by changing the timing of snowmelt to affect predator:prey dynamics. Early snowmelt allowed coyotes (Canis latrans) access to sites occupied by Olympic marmots. About 30\% of adult females were killed each year (2002 to 2006) when snowpack was low. But more recently when snowpacks were above average, the loss of adult females dropped to 0 to $10 \%$ each year [43].

Climate change may indirectly affect individual fitness rather than mortality or habitat loss by increasing the frequency of extra pair paternity (EPP) where a female mates with a male other than the territorial male of her family group. In alpine marmots, EPP occurred at sites already free of snow during the mating season. Early snowmelt may allow more movement by adult males and EPP by transients [44] whereas heavy snowpack normally restricts movements between alpine marmot families [45].

An important impact of climate change is expressed through weather extremes. One consequence of earlier emergence from hibernation was the lengthening of the growing season for yellow-bellied marmots. The longer growing season produced a pattern of coupled dynamics 
of body mass and population growth. Larger body mass at hibernation increased survival, especially of adult females between 2000 and 2008 [46]. Population numbers more than doubled. However, prolonged snow cover in the winter of 2010-2011 resulted in the mortality of about $50 \%$ of the adults and $80 \%$ of the young of 2010 and reduced reproduction in 2011 [47]. Prolonged snow cover also increased mortality in Vancouver Island marmots [6] and reduced reproduction at high elevation sites occupied by Olympic marmots [43].

The other extreme weather event is drought. Prolonged drought may induce mass extinctions in the tarbagan and increase emigration, which can promote a plague epidemic in gray marmots and tarbagan [48]. Drought reduced survivorship of young and reproductive adult female yellow-bellied marmots. Mortality occurred because the marmots failed to gain sufficient mass to survive hibernation [49]. The drought was followed three years later by a year of late snowmelt; the combination negatively impacted the marmot populations, some sites went extinct, and the impact differed markedly among populations separated by $125 \mathrm{~m}$ elevation and $7 \mathrm{~km}$ distance [25]. Recovery of impacted populations and recolonization of extinct sites was slow because the age structure and social dynamics of the survivors decreased reproduction. This event indicates that climate change impacts may be local rather than widespread. Also, the negative impacts of extreme weather events likely depend on their frequency of occurrence and will be more severe when drought and late snowmelt occur closely in time.

Marmots may move locally in response to the extreme weather events. When snow cover persisted for a long time, gray marmots migrated as much as $0.5 \mathrm{~km}$ to areas where forage was available. Tarbagan moved out of narrow mountain valleys stricken with drought to hilly meadows. In a subsequent year when low temperatures inhibited plant growth in the hilly meadows, the marmots moved 2 to $3 \mathrm{~km}$ downslope to the valleys where green vegetation was abundant [48]. These movements demonstrate that marmots have some flexibility in responding to short-term severe weather events.

\section{FUTURE PROSPECTS}

Global warming and weather extremes are expected to continue into the foreseeable future [12]. In the short term, some marmot populations may increase if warming is associated with early snowmelt. Large areas in central Tadzhikistan are not occupied by the long-tailed marmot because of prolonged snow cover [23]. In the range of the Olympic marmot some meadows have unoccupied burrows indicating that marmots had lived there. A survey of those meadows over several years revealed that in years with heavy snowpack and late snowmelt, the mea- dows were completely snow covered well beyond the time marmots would need to forage to remain alive [43]. In these cases, and most likely in other geographic areas inhabited by marmots, warming and early snowmelt will increase the habitat available for marmot colonization.

Early snowmelt alters plant and animal phenology [50]. The annual cycle of marmots evidences considerable phenotypic plasticity in the timing of emergence into and immergence from hibernation. Marmots at semi-arid low elevation sites emerge and immerge about two months earlier than marmots at high elevation sites [51]. Thus, marmots should have no problem adjusting their phenology to seasonal shifts in snowmelt patterns.

What is more problematical is the future distribution of drought conditions. The climate in western United States has warmed markedly and is predicted to continue to do so coupled with a reduction in precipitation [52]. Warming is expected to increase lowland aridity and may isolate boreal faunas, including marmots, on Great Basin Mountain tops as these populations will no longer be linked by dispersal [53]. Isolation likely will lead to extinction of some of these populations because of stochastic population decline.

Low elevation yellow-bellied marmot populations that express physiological adaptations to aridity probably can survive, although they likely will shift their distribution upward [16,39]. However, the upward shift will be successful only if individual marmots can disperse to and colonize habitats that may be occupied by conspecifics. Marmots are known to disperse as far as $15 \mathrm{~km}$ [54]. However, successful immigration into an established marmot colony is uncommon unless the colony is depopulated because of poor recruitment of offspring [55].

High elevation marmots likely will face a higher frequency of droughts. As described previously, drought increases mortality during the subsequent hibernation and decreases reproductive output the following year. Effects would be especially devastating if a drought summer is followed by late snowmelt the following spring [25]. Marmots are long-lived [56] and if severe weather does not occur too often, the population should avoid extinction.

As described in an early section of this paper, where human intervention directly threatened marmot survival, conservation practices prevented extinction. There is little likelihood that human intervention, short of stopping global warming, can ameliorate climate effects on marmot populations. Upslope movements are limited; eventually there is no place to move to. Meadows could be kept tree-free by removal, but that would require a very extensive and expensive effort which is unlikely to ever become a priority activity as humans respond to the effects of climate change.

Marmots demonstrate considerable plasticity in the 
specific characteristics of their habitats, e.g., digging burrows under buildings instead of rocks, and in the plants on which they feed [2]. Thus, they can colonize and persist for years in marginal habitat [48]. If marmots are protected from human destruction, they can colonize these habitats that may become available as climate change with its severe weather pattern impacts mountain ecosystems.

Widespread species, such as the woodchuck, yellowbellied, gray, and steppe marmots, are not seriously threatened, although some local populations likely will go extinct. Those species with a restricted, high elevation distribution, such as the Olympic, Vancouver Island, and Alaskan marmots, are threatened because of climate change induced habitat loss. One way to preserve threatened and/or critically endangered species is by captive breeding. Marmots successfully reproduce in captivity and considerable information is available on how to maintain a captive, reproductive population [6,48]. A captive breeding program is unlikely to maintain the diversity now present in local populations (as expressed in the number of described sub-species [2]), but can preserve a species until such time that the species can recolonize a natural environment. However, if climate change eliminates the meadow environment of high-elevation species, recolonization will not be possible.

\section{REFERENCES}

[1] Steppan, S.J., Kenagy, G.J., Zawadzski, C., Robles, R., Lyapunova, E.A. and Hoffman, R.S. (2011) Molecular data resolve placement of the Olympic marmot and estimate dates of trans-Beringian interchange. Journal of Mammalogy, 92, 1028-1037.

doi:10.1644/10-MAMM-A-272.1

[2] Armitage, K.B. (2000) The evolution, ecology, and systematics of marmots. Oecologia Montana, 9, 1-8.

[3] Nagorsen, D.W. (1987) Marmota vancouverensis. Mammalian Species, 270, 1-5. doi:10.2307/3503862

[4] Bryant, A.A. (1996) Reproduction and persistence of Vancouver Island marmots (Marmota vancouverensis) in natural and logged habitats. Canadian Journal of Zoology, 74, 678-687. doi:10.1139/z96-076

[5] Bryant, A.A. and Janz, D.W. (1996) Distribution and abundance of Vancouver Island marmots (Marmota vancouverensis). Canadian Journal of Zoology, 74, 667-677. doi:10.1139/z96-075

[6] Doyle, D. (2011) Vancouver Island marmot project. Final report, $19 \mathrm{p}$.

[7] Bryant, A.A. and Page, R.E. (2005) Timing and cause of mortality in the endangered Vancouver Island Marmot (Marmota vancouverensis). Canadian Journal of Zoology, 83, 674-682. doi:10.1139/z05-055

[8] Batbold, J. (2002) The problem of management of marmots in Mongolia. In: Armitage, K.B. and Rumiantsev, V.Yu., Eds., Holarctic Marmots as a Factor of Biodiver- sity, ABF Publishing House, Moscow, 69-75.

[9] Kolesnikov, V.V., Brandler, O.V., Badmaev, B.B., Zoje, D. and Adiya, Ya. (2009) Factors that lead to a decline in numbers of Mongolian marmot populations. Ethology Ecology \& Evolution, 21, 371-379. doi:10.1080/08927014.2009.9522492

[10] Stephens, P.A., Frey-Roos, F., Arnold, W. and Sutherland, W.J. (2002) Sustainable exploitation of social species: A test and comparison of models. Journal of Applied Ecology, 39, 629-642. doi:10.1046/j.1365-2664.2002.00740.x

[11] Le Berre, M. and Ramousse, R. (2003) Organizing biodiversity conservation for the genus Marmota. In: Ramousse, R., Allainé, D. and Le Berre, M., Eds., Adaptive Strategies and Diversity in Marmots, International Marmot Network, Lyon, 235-244.

[12] Carr, P.H. (2013) Weather extremes from anthropogenic global warming. Natural Science, 5, 130-134. doi:10.4236/ns.2013.51A020

[13] Mein, P. (1992) Taxonomy. In: Bassano, B., Durio, P., Gallo Orsi, U. and Macchi, E., Eds., Proceedings of the 1st International Symposium on Alpine Marmot and on Genus Marmota, Torino, 6-12.

[14] Armitage, K.B. (2007) Evolution of sociality in marmots: It begins with hibernation. In: Wolff, J.O. and Sherman, P.W., Eds., Rodent Societies: An Ecological and Evolutionary Perspective, University of Chicago Press, Chicago, 356-367.

[15] Armitage, K.B. and Blumstein, D.J. (2002) Body-mass diversity in marmots. In: Armitage, K.B. and Rumiantsev, V.Yu., Eds., Holarctic Marmots as a Factor of Biodiversity, ABF Publishing House, Moscow, 22-32.

[16] Armitage, K.B., Melcher, J.C. and Ward Jr., J.M. (1990) Oxygen consumption and body temperature in yellowbellied marmot populations from montane-mesic and lowland-xeric environments. Journal of Comparative Physiology B, 160, 491-502. doi:10.1007/BF00258976

[17] Armitage, K.B. (1994) Unusual mortality in a yellowbellied marmot population. In: Rumiantsev, V.Yu., Ed., Actual Problems of Marmots Investigation, ABF Publishing House, Moscow, 5-13.

[18] Liow, L.H., Fortelius, M., Lintulaakso, K., Mannila, H. and Stenseth, N.C. (2009) Lower extinction risk in sleepor-hide mammals. American Naturalist, 173, 264-272. doi:10.1086/595756

[19] Armitage, K.B. (1991) Social and population dynamics of yellow-bellied marmots: Results from long-term research. Annual Review of Ecology and Systematics, 22, 379-407. doi:10.1146/annurev.es.22.110191.002115

[20] Armitage, K.B. (2009) Fur color diversity in marmots. Ethology Ecology \& Evolution, 21, 183-194.

[21] Melcher, J.C., Armitage, K.B. and Porter, W.P. (1990) Thermal influences on the activity and energetics of yellow-bellied marmots (Marmota flaviventris). Physiological Zoology, 63, 803-820.

[22] Suntsov, V.V. and Suntsova, N.I. (1991) Spatial structure of the tarbagan in Tuva. In: Bibikov, D.I., Nikolski, A.A., Rumiantsev, V.Yu. and Seredneva, T.A., Eds., Population Structure of the Marmot, USSR Theriological Society, 
Moscow, 217-232.

[23] Davydov, G.S. (1991) Some characters of two populations of the long-tailed marmot. In: Bibikov, D.I., Nikolski, A.A., Rumiantsev, V.Yu. and Seredneva, T.A., Eds., Population Structure of the Marmot, USSR Theriological Society, Moscow, 188-216.

[24] Van Vuren, D. and Armitage, K.B. (1991) Duration of snow cover and its influence on life-history variation in yellow-bellied marmots. Canadian Journal of Zoology, 69, 1755-1758. doi:10.1139/z91-244

[25] Armitage, K.B. (2003) Recovery of a yellow-bellied marmot population following a weather-induced decline. In: Ramousse, R., Allainé, D. and Le Berre, M., Eds., Adaptive Strategies and Diversity in Marmots, International Marmot Network, Lyon, 217-224.

[26] Johns, D.W. and Armitage, K.B. (1979) Behavioral ecology of alpine yellow-bellied marmots. Behavioral Ecology and Sociobiology, 5, 133-157. doi:10.1007/BF00293302

[27] Woods, B.C., Brown, C.L. and Cobb, M.A. (2009) Elevation variation in life-history characteristics of populations of yellow-bellied marmots (Marmota flaviventris). Ethology Ecology \& Evolution, 21, 381-392. doi:10.1080/08927014.2009.9522493

[28] Mosolov, V.I. and Tokarsky, V.A. (1994) The black-capped marmot (Marmota camtschatica Pall.) in the Kronotsky Reserve. In: Rumiantsev, V.Yu., Ed., Actual Problems of Marmots Investigation, ABF Publishing House, Moscow, 98-110.

[29] Arnold, W. (1993) Energetics of social hibernation. In: Carey, C., Florant, G.L., Wunder, B.A. and Horwitz, B., Eds., Life in the Cold: Biological, Physiological, and Molecular Mechanisms, Westview Press, Boulder, 65-80.

[30] Barash, D.P. (1973) The social biology of the Olympic marmot. Animal Behaviour Monographs, 6, 173-245. doi:10.1016/0003-3472(73)90002-X

[31] Griffin, S.C. (2007) Female Olympic marmots (Marmota olympus) reproduce in consecutive years. American Midland Naturalist, 158, 221-225. doi:10.1674/0003-0031(2007)158[221:FOMMOR]2.0.C $\underline{\mathrm{O} ; 2}$

[32] Karels, T.J. and Hik, D.S. (2003) Demographic responses of hoary marmots (Marmota caligata) to environmental variation. In: Ramousse, R., Allainé, D. and Le Berne, M., Eds., Adaptive Strategies and Diversity in Marmots, International Marmot Network, Lyon, 167-168.

[33] Allainé, D., Cohas, A. and Bonenfant, C. (2008) Demographic effects of climate fluctuations on an alpine marmot (Marmota marmota) population. 6th International Marmot Conference, Cogne, 3-6 September 2008, 12-13.

[34] Cushing Jr., J.E. (1945) Quaternary rodents and lagomorphs of San Josecita Cave, Nueva Leon, Mexico. Journal of Mammalogy, 26, 182-185. doi:10.2307/1375094

[35] Goodwin, H.T. (1989) Marmota flaviventis from the Central Mohave Desert of California: Biogeographic implications. The Southwestern Naturalist, 34, 284-287. doi:10.2307/3671741

[36] Kalthoff, D.C. (1999) Jungpleistozäne Murmeltiere (Ro- dentia, Sciuridae) vom Mittelrheim (Deutschland) und ihre verwandtschaftlichen Beziehungen zu den beiden rezenten europäischen Anten. Staphia, 63, 119-128.

[37] Inouye, D.W., Barr, B., Armitage, K.B. and Inouye, B.D. (2000) Climate change is affecting altitudinal migrants and hibernating species. Proceedings of the National Academy of Science of the United States of America, 97, 1630-1633. doi:10.1073/pnas.97.4.1630

[38] Davis, E.B. (2005) Comparison of climate space and phylogeny of Marmota (Mammalia: Rodentia) indicates a connection between evolutionary history and climate preference. Proceedings of the Royal Society B, 272, 519526. doi:10.1098/rspb.2004.2979

[39] Waltari, E. and Guralnick, R.P. (2009) Ecological niche modeling of montane mammals in the Great Basin, North America: Examining past and present connectivity of species across basins and ranges. Journal of Biogeography, 36, 148-161. doi:10.1111/j.1365-2699.2008.01959.x

[40] Bykova, E. and Esipov, A. (2008) Climate change impacts on population of menzbier's marmot (Marmota menzbieri) in Uzbekistan. 6th International Marmot Conference, Tashkent, 31 August-2 September 2005, 13.

[41] Gunderson, A.M., Lanier, H.C. and Olson, L.E. (2012) Limited phylogeographic structure and genetic variations in Alaska's arctic and alpine endemic, the Alaska marmot. Journal of Mammalogy, 93, 66-75. doi:10.1644/10-MAMM-A-380.1

[42] Griffin, S.C., Griffin, P.C., Taper, M.L. and Mills, L.S. (2009) Marmots on the move? Dispersal in a declining montane mammal. Journal of Mammalogy, 90, 686-695. doi:10.1644/08-MAMM-A-159R1.1

[43] Griffin, S.C. (2011) Personal communication.

[44] Cohas, A., Bonenfant, C., Gaillard, J.-M. and Allainé, D. (2007) Are extra-pair young better than within-pair young? A comparison of survival and dominance in alpine marmots. Journal of Animal Ecology, 76, 771-778. doi:10.1111/j.1365-2656.2007.01253.x

[45] Arnold, W. (1990) The evolution of marmot sociality: 1. Why disperse late? Behavioral Ecology and Sociobiology, 27, 229-237.

[46] Ozgul, A., Childs, D.Z., Oli, M.K., Armitage, K.B., Blumstein, D.T., Olson, L.E., Tuljapurkar, S. and Coulson, T. (2010) Coupled dynamics of body mass and population growth in response to environmental change. Nature, 466, 482-485. doi:10.1038/nature09210

[47] Blumstein, D.T. (2011) Personal communication.

[48] Bibikow, D.I. (1996) Die murmeltiere der welt. Westarp Wissenchaften, Magdeburg.

[49] Armitage, K.B. (1994) Unusual mortality in a yellowbellied marmot population. In: Rumiantev, V.Yu., Ed., Actual Problems of Marmots Investigation, ABF Publishing House, Moscow, 5-13.

[50] Lambert, A.M., Miller-Rushing, A.J. and Inouye, D.W. (2010) Changes in snowmelt and summer precipitation affect the flowering phenology of Erythronium grandiflorum (Glacier lily; Liliacae). American Journal of Botany, 97, 1431-1437. doi:10.3732/ajb.1000095

[51] Armitage, K.B. (2005) Intraspecific variation in marmots. 
In: Sanchez-Cordero, V. and Medellin, R.A., Eds., Contribuciones, Mastozoologicas en Homenaje a Bernardo Villa, Instituto de Biologia, UNAM, Instituto de Ecologia, UNAM, CONABIO, Mexico, 39-48.

[52] Overpeck, J. and Udall, B. (2010) Dry times ahead. Science, 328, 1642-1643. doi:10.1126/science.1186591

[53] Floyd, C.H., Van Vuren, D.H. and May, B. (2005) Marmots on Great Basin mountaintops: Using genetics to test a geographic paradigm. Ecology, 86, 2145-2153. doi:10.1890/04-1227
[54] Van Vuren, D. (1990) Dispersal of yellow-bellied marmots. Ph.D. Dissertation, The University of Kansas, Lawrence.

[55] Armitage, K.B. (2003) Dynamics of immigration into yellow-bellied marmot colonies. Oecologia Montana, 12, 21-24.

[56] Schwartz, O.A., Armitage, K.B. and Van Vuren, D. (1998) A 32-year demography of yellow-bellied marmots. Journal of Zoology, London, 246, 37-346. doi:10.1111/j.1469-7998.1998.tb00163.x 